Web Jurnal:

\title{
Biomordan gambir pada pewarnaan kain viskos menggunakan ekstrak pewarna dari limbah kulit jengkol (Archidendron jiringa)
}

\section{Gambier biomordant in dyeing of viscous fabric using dye extract of dogfruit pod waste (Archidendron jiringa)}

\author{
F Failisnur*, S Sofyan, S Silfia, Salmariza Sy, A Ardinal \\ Balai Riset dan Standardisasi Industri Padang \\ Jl. Raya LIK No. 23 Ulu Gadut Padang 25164, Indonesia \\ * e-mail: failisnur@gmail.com
}

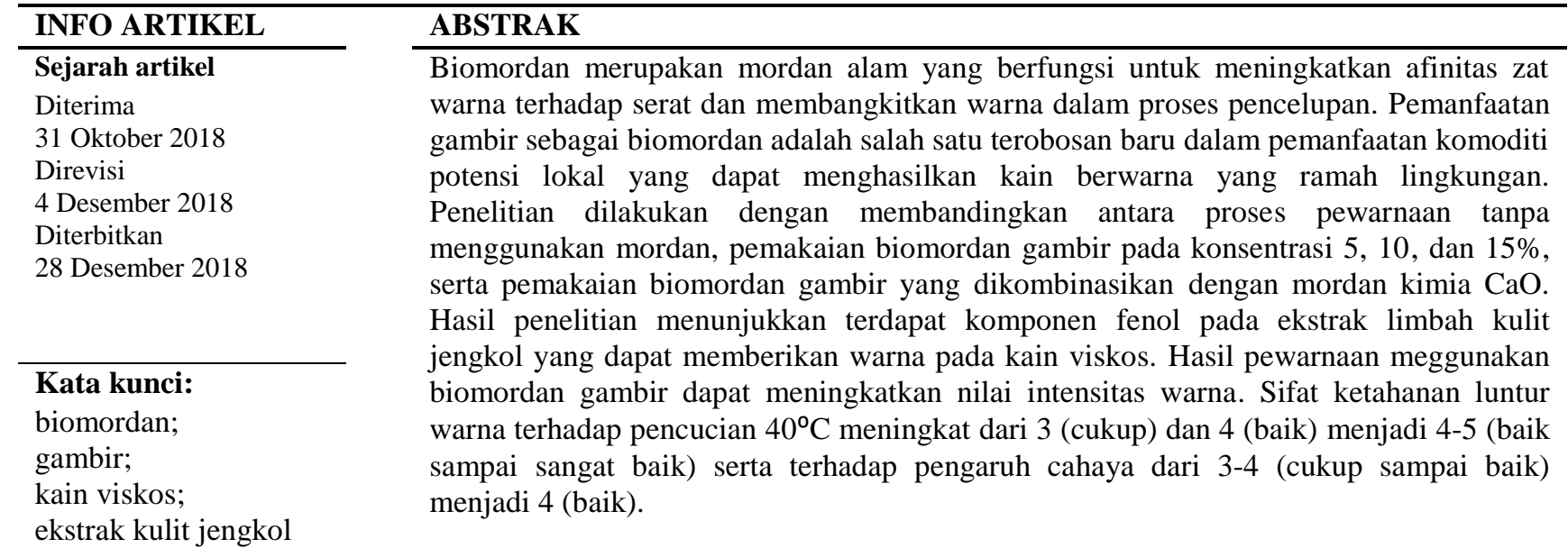

\section{Keywords: \\ biomordant; \\ gambier; \\ viscous fabric; \\ dogfruit pod extract}

\begin{abstract}
The biomordant is a natural mordant that functions to increase the affinity of dyes to the fiber and generate color in the dyeing process. The use of gambier as a biomordant is one of inovation in the utilization of local potential commodities that can produce ecofriendly coloring fabrics. The study was conducted by comparing the dyeing process without using mordant, the use of biomordant gambier at a concentration of 5, 10, and $15 \%$, as well as the use of biomordant gambier was combined with CaO chemical mordant. The results showed that there were phenol components in the extract of dogfruit pod waste which could give color to the viscous fabric. The coloring results using gambier biomordant could increase the color intensity value. The color fastness characteristics of washing $40^{\circ} \mathrm{C}$ increased from 3 (fairly good) and 4 (good) to 4-5 (good to very good) and to the fastness of light raised from 3-4 (fairly good to good) to 4 $($ good $)$.
\end{abstract}

(C) 2018 Penulis. Dipublikasikan oleh Baristand Industri Padang. Akses terbuka dibawah lisensi CC BY-NC-SA

\section{Pendahuluan}

Mordan merupakan komponen penting dari proses pencelupan alami dalam mendapatkan berbagai corak dan sifat tahan luntur warna. Sebagian besar pewarna alami tidak memiliki substantivitas untuk serat tekstil sehingga memerlukan bantuan mordan untuk meningkatkan afinitasnya terhadap serat. Mordan biasanya berasal dari garam logam seperti tawas, krom, stannous klorida, tembaga dan besi sulfat. Bahan kimia ini bertindak sebagai mordan dengan menjembatani ikatan antara pewarna dengan serat, sehingga terbentuk ligan antara serat dan pewarna (Wangatia et al., 2015). Kompleksitas antara serat-pewarna-ion logam secara signifikan dapat mengubah struktur morfologi dan perilaku termal dari serat kain dan memberikan 
serangkaian fungsi seperti tahan luntur, tahan api, antioksidan dan sifat antibakteri (Ghaheh et al., 2014; Yang et al., 2018).

Penggunaan mordan kimia berupa garam logam selama pencelupan terkadang menimbulkan keraguan pada pewarnaan alami yang ramah lingkungan. Sebahagian kecil garam logam akan tinggal di serat tekstil dan sisanya dibuang sebagai limbah yang dapat mencemari sumber daya air dan tanah. Selain itu, kehadiran beberapa garam logam ini berhubungan langsung dengan pengguna tekstilnya.

Beberapa penelitian penggunaan mordan logam pada pewarnaan tekstil yang telah dipelajari diantaranya adalah pemakaian logam aluminium, ferrous, stannous, kromium, dan sodium (Islam et al., 2017; Masae et al., 2017; Sofyan and Failisnur, 2017). Pada proses pewarnaan tekstil, logam kromium tidak boleh digunakan karena tidak ramah lingkungan. Logam tembaga termasuk kategori terbatas tetapi masih diperbolehkan dalam jumlah kecil. Sementara pemakaian logam timah tidak dibatasi hanya saja limbahnya dapat mencemari lingkungan. Aluminium dan besi dapat dianggap sebagai mordan dengan dampak ekologis yang lebih aman (Saxena and Raja, 2014; Zarkogianni et al., 2011).

Beberapa pendekatan telah dilakukan dalam penggunaan bahan alami sebagai biomordan ramah lingkungan diantaranya adalah tanin biji tamarin (Prabhu and Teli, 2014), bunga rosemary, daun Thuja occidentalis dan kulit buah delima (Ismal et al., 2014) klorofil a (Guesmi et al., 2013). Namun belum ada yang mengkaji tentang penggunaan tanin dari gambir sebagai biomordan.

Tanin gambir mengandung senyawa fenolik hidroksil yang dapat berfungsi sebagai mordan membentuk kompleks dengan molekul zat warna. Komplek ini menyebabkan fiksasi pada proses pewarnaan. Penggunaan biomordan biasanya disubstitusi dengan mordan logam membentuk tannat logam untuk meningkatkan intensitas dan ketahanan luntur warna serat (Prabhu and Teli, 2014). Penggunaan tanin gambir sebagai biomordan disebabkan karena ketersediaan dan potensinya yang cukup. Gambir merupakan tanaman budidaya dan sudah di ekspor ke berbagai negara.

Tujuan penelitian ini adalah untuk melihat penggunaan gambir sebagai biomordan dan kombinasinya dengan mordan kimia dalam pewarnaan kain viskos menggunakan pewarna kulit jengkol. Penggunaan mordan ini juga dibandingkan dengan tanpa pemakaian mordan dalam menghasilkan intensitas dan ketahanan luntur warna kain hasil celupan. Viskos merupakan serat alam yang dikembangkan dari serat rayon. Kulit jengkol merupakan limbah yang tidak bermanfaat tetapi masih mengandung tanin sebesar $5,28 \%$ yang dapat berfungsi sebagai pewarna (Sofyan et al., 2018).

\section{Metode}

Bahan utama yang digunakan dalam penelitian ini adalah gambir asalan yang diperoleh dari petani gambir di Desa Siguntur Kabupaten Pesisir Selatan, Indonesia. Kulit jengkol diambil dari pedagang jengkol di Pasar
Bandar Buat Padang, kain viskos dari pedagang di pasar kain di Yogyakarta. Bahan bantu penelitian berupa $\mathrm{CaO}$ merk bratako keluaran bratachem.

Peralatan proses yang digunakan meliputi crusher (penghalus gambir), filter $400 \mathrm{mesh}$, alat-alat gelas, peralatan untuk uji FTIR menggunakan FTIR spectrum Perkin Elmer. Spectrophotometer colorscan SS 6000 untuk uji intensitas warna. Laundrymeter, crockmeter, gray scale dan staining scale untuk evaluasi ketahanan luntur warna terhadap pencucian dan sinar.

\subsection{Rancangan Penelitian}

Penelitian dilakukan dengan variasi perlakuan yang terdiri dari: pewarnaan kain viskos dengan kulit jengkol tanpa menggunakan mordan, penggunaan biomordan tanin gambir 5\%, 10\%, dan $15 \%$ serta penggunaan mordan gabungan (tanin gambir $10 \%$ dan $\mathrm{CaO} 5 \%$ ).

\subsection{Pelaksanaan penelitian}

Penelitian dilakukan melalui tahapan: (1) ekstraksi dari pewarna alam kulit jengkol, (2) ekstraksi ulang gambir asalan untuk mendapatkan kadar tanin tinggi, (3) pembuatan larutan biomordan dari gambir dan kombinasi dengan mordan logam, (4) proses pencelupan dan mordanting, (5) proses finishing untuk membuang larutan pewarna yang tidak terikat kuat pada serat kain.

\subsubsection{Ekstraksi pewarna dari kulit jengkol}

Ekstraksi dilakukan dengan merebus kulit jengkol menggunakan pelarut air. Kulit jengkol terlebih dahulu direndam dalam air dengan perbandingan 1:1. Selanjutnya kulit jengkol direbus bersama air rendamannya sampai air rebusannya menjadi setengah bagian, lalu didinginkan. Air rebusan disaring dengan kain saring (Sofyan et al., 2018). Ekstrak yang diperoleh siap digunakan sebagai pewarna.

\subsubsection{Ekstraksi ulang gambir asalan}

Gambir asalan dihaluskan dan dilarutkan dalam air panas mendidih $\left( \pm 100^{\circ} \mathrm{C}\right)$ sambil diaduk supaya larut. Filtrasi larutan menggunakan filter 400 mesh, kotoran yang sudah terpisah dibuang dan filtrat dipanaskan \pm 15 menit. Selama pemanasan, terus dilakukan pengadukan untuk mempercepat proses pelarutan. Larutan kemudian diendapkan \pm 24 jam. Supernatan yang dihasilkan dapat dimanfaatkan sebagai biomordan.

\subsubsection{Proses pencelupan dan mordanting}

Proses awal pewarnaan kain viskos dilakukan melalui pencelupan kain yang sudah dikelantang di dalam ekstrak kulit jengkol selama \pm 30 menit pada suhu $\pm 60^{\circ} \mathrm{C}$. Kain celupan kemudian dikering anginkan sampai kadar airnya diperkirakan 25-30\% (Failisnur et al., 2018). Kain kemudian dicelup ulang sampai tiga kali pencelupan, lalu dijemur di tempat teduh.

Kain yang telah diwarnai dengan ekstrak kulit jengkol, lalu dilakukan proses mordan. Metoda mordan yang digunakan adalah pasca mordanting. Metoda pasca 
mordanting memberikan intensitas dan ketahanan luntur warna yang lebih baik dibandingkan dengan metoda pra ataupun simultan mordanting (Failisnur et al., 2018). Zat mordan yang digunakan dalam penelitian ini adalah biomordan dari tanin gambir yang dikombinasikan dengan mordan logam.

\subsubsection{Proses finishing}

Langkah terakhir dari proses pewarnaan adalah proses finishing melalui perendaman dalam air panas yang dilanjutkan dengan pencucian dalam air dingin (Failisnur and Sofyan, 2014). Pencucian dihentikan setelah air lunturnya hilang. Selanjutnya kain dijemur di tempat teduh, karena beberapa zat warna alam kurang tahan terhadap paparan sinar matahari langsung.

\subsection{Analisis dan pengamatan}

Pengamatan FTIR dilakukan terhadap ekstrak kulit jengkol dan tanin gambir. Sedangkan terhadap kain hasil pewarnaan dievaluasi nilai intensitas (K/S) warna dan uji beda warna, serta ketahanan luntur warna terhadap pencucian dan cahaya.

\subsubsection{Uji FTIR}

Analisis gugus fungsi dari ekstrak kulit jengkol dan kain hasil pewarnaan menggunakan biomordan tanin gambir dilakukan dengan menggunakan Spektroskopi FTIR (Fourier Transform Infrared Spectrometer). Sampel ekstrak kulit jengkol diletakkan dikaca objek dan di identifikasi dengan spektrofotometer FTIR pada panjang gelombang $4000-400 \mathrm{~cm}^{1}$ (Sulistyani and Huda, 2017).

\subsubsection{Pengamatan intensitas dan nilai beda warna}

Sifat-sifat kolorimetrik dari sampel kain viskos yang dicelup diperoleh dengan menggunakan Spectrophotometer colorscan SS 6000, pada illuminan D65 $10^{\circ}$ untuk mendapatkan nilai CIELab (L*, a*, b*, $\left.\mathrm{c}^{*}, \mathrm{~h}^{*}\right)$ dan intensitas warna $(\mathrm{K} / \mathrm{S})$. Intensitas warna pada spektrum tampak (400-700) nm yang dihitung berdasarkan persamaan; K/S $=(1-\mathrm{R}) 2 / 2 \mathrm{R}$ (Kubelka Munk)

\subsubsection{Evaluasi ketahanan luntur warna}

Evaluasi ketahanan luntur warna terhadap pencucian dilakukan menurut ISO 105-C0661-2003. Sampel dicuci selama 30 menit dalam bacth yang mengandung $4 \mathrm{~g} / \mathrm{L}$ deterjen dan $2 \mathrm{~g} / \mathrm{L} \mathrm{Na}_{2} \mathrm{CO}_{3}$ pada suhu $50^{\circ} \mathrm{C}$ pada rasio 1:50. Perubahan warna dievaluasi menggunakan gray scale. Ketahanan luntur warna terhadap cahaya diuji sesuai dengan ISO 105- B02. Besarnya pemudaran warna terhadap paparan cahaya dibandingkan dengan standar. Hasil evaluasi dinilai sebagai berikut: nilai 5 (baik sekali, tidak ada perubahan warna kain atau penodaan warna terhadap bahan lain), nilai 4 (baik, sedikit terjadi perubahan atau penodaan warna), nilai 3 (cukup, terjadi perubahan atau penodaan warna), nilai 2 (sedang, terjadi perubahan atau penodaan warna yang menyolok) dan nilai 1 (kurang, terjadi perubahan dan penodaan warna yang sangat menyolok).

\section{Hasil dan pembahasan \\ 3.1. Identifikasi ekstrak jengkol dengan FTIR}

Ekstrak kulit jengkol diidentifikasi dengan spektrofotometer FTIR untuk mengetahui gugus fungsi komponen. Pengukuran dilakukan pada daerah bilangan gelombang $4000 \mathrm{~cm}^{-1}-400 \mathrm{~cm}^{-1}$. Hasil analisis ekstrak kulit jengkol dapat dilihat pada Gambar 1. Hasil analisis menunjukkan limbah kulit jengkol mempunyai beberapa gugus fungsi yang diperkirakan berperan dalam proses pewarnaan. Terlihat limbah kulit jengkol mempunyai tiga puncak gelombang utama pada bilangan gelombang $3428,40 \mathrm{~cm}^{-1}(1,76 \% \mathrm{~T}), 1622,59 \mathrm{~cm}-1(10,12 \% \mathrm{~T})$ dan $733,77 \mathrm{~cm}^{-1}(40,34 \% \mathrm{~T})$. Pita serapan kuat pada antara $3000 \mathrm{~cm}^{-1}-3500 \mathrm{~cm}^{-1}$ dapat dikaitkan dengan mode vibrasi peregangan dari ikatan $\mathrm{O}-\mathrm{H}$ dalam permukaan gugus hidroksil atau molekul air teradsorpsi. Puncak ke dua pada daerah $1622 \mathrm{~cm}^{-1}$ dapat dikaitkan dengan mode vibrasi peregangan dari ikatan gugus fungsional karboksil $\mathrm{C}=\mathrm{O}$ atau ikatan group fungsional alkena $\mathrm{C}=\mathrm{C}$. Puncak ketiga ditemukan pada $689 \mathrm{~cm}^{-1}-793 \mathrm{~cm}^{-1}$ yang dikaitkan dengan ikatan $\mathrm{Si}-\mathrm{O}$ dalam kelompok $\mathrm{SiO}_{4}$.

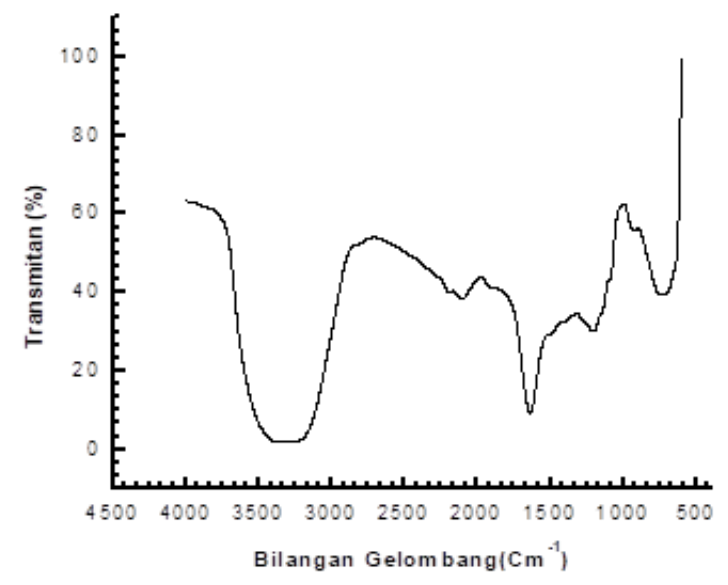

Gambar 1. Spektrum FTIR dari ekstrak kulit jengkol

\subsection{Karakterisasi kain hasil pewarnaan \\ 3.2.1. Identifikasi FTIR kain hasil pewarnaan dengan kulit jengkol}

Spektrum FTIR perlakuan penggunaan biomordan gambir dan tanpa mordan diperlihatkan pada Gambar 2. Hasil penelitian menunjukkan intensitas serapan maksimum terjadi pada bilangan gelombang 1.023,61 $\mathrm{cm}^{-1}$ dan 3.326,23 $\mathrm{cm}^{-1}$ untuk kain tanpa mordan. Sedangkan untuk kain dengan biomordan terjadi pada bilangan gelombang $1.025,15 \mathrm{~cm}^{-1}$ dan $3.326,74 \mathrm{~cm}^{-1}$. Dari Gambar 2 terlihat bahwa puncak gelombang utama terletak antara $3292 \mathrm{~cm}^{-1}-3326 \mathrm{~cm}^{-1}$ dapat dikaitkan dengan adanya kelompok gugus fungsional hidroksil O$\mathrm{H}$, dan pada $1025 \mathrm{~cm}^{-1}$ ditemukan kelompok gugus fungsional karboksil C-O. Puncak gelombang lainnya ditemukan pada $2893 \mathrm{~cm}^{-1}$ dan $1329 \mathrm{~cm}^{-1}$ pada ke dua perlakuan menujukkan vibrasi C-H. Puncak kecil pada $2146 \mathrm{~cm}^{-1}-2156 \mathrm{~cm}^{-1}$ sesuai dengan mode getaran peregangan $\mathrm{C} \equiv \mathrm{N}$ atau ikatan $\mathrm{C} \equiv \mathrm{N}$. Puncak pada 1625 
$\mathrm{cm}^{-1}$ dapat dikaitkan dengan mode getaran peregangan ikatan $\mathrm{C}=\mathrm{O}$ atau ikatan $\mathrm{C}=\mathrm{C}$. Puncak pada puncak kecil lainnya ditemukan pada $665 \mathrm{~cm}^{-1}$ yang dikaitkan dengan ikatan $\mathrm{Si}-\mathrm{O}$ dalam kelompok $\mathrm{SiO}_{4}$. Diperkirakan semua gugus fungsi tersebut berperan dalam penguatan serapan zat warna pada kain viskos, terutama gugus fungsi hidroksil dan karboksil. Hal ini menunjukkan bahwa intensitas puncak serapan berhubungan dengan peregangan $\mathrm{O}-\mathrm{H}$ fenol dan $\mathrm{C}-\mathrm{OH}$, yang mengindentifikasikan bahwa senyawa memiliki gugus fungsi hidroksil (Liang et al., 2010).
Penyerapan warna antara perlakuan pemakaian boimordan dan tanpa mordan terlihat berbeda dalam persentase transmitan, dimana pemakaian biomordan gambir memberikan persentase transmittan yang lebih tinggi dibandingkan tanpa pemakaian biomordan. Termasuk puncak pada $1025 \mathrm{~cm}^{-1}$ yang terlihat adanya perbedaan persentase transmitan, setelah dilakukan perbesaran (Gambar 2). Hal ini disebabkan karena pemakaian biomordan dapat meningkatkan afinitas zat warna terhadap serat kain sehingga akan menyebabkan semakin banyak molekul zat warna yang terikat ke dalam serat kain.

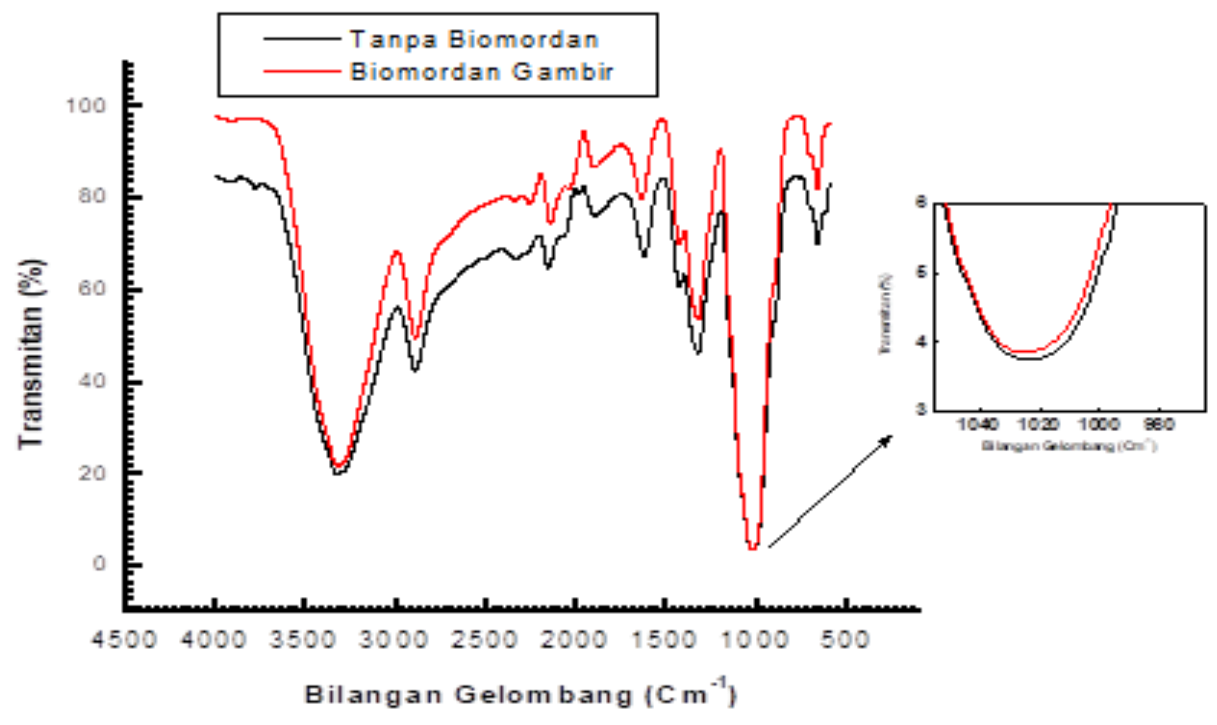

Gambar 2. Spektrum FTIR dari kain hasil pewarnaan

\subsection{Intensitas dan nilai beda warna}

Intensitas warna (K/S) dan nilai beda warna dari kain hasil pewarnaan dengan pewarna kulit jengkol ditampilkan pada Tabel 1. Nilai K/S terendah adalah 1,36, sedangkan K/S tertinggi adalah 3,70. Penggunaan biomordan gambir dapat meningkatkan nilai intensitas warna. Semakin tinggi konsentrasi biomordan, intensitas warna yang dihasilkan juga semakin meningkat dengan nilai K/S 1,96; 2,28; dan 2,52 berturut-turut untuk biomordan gambir 5, 10, dan 15\%. Konsentrasi mordan dapat mempengaruhi nilai intensitas warna (Khan et al., 2016; Punrattanasin et al., 2013).

Penggunaan biomordan gambir yang digabungkan dengan penambahan mordan logam $\mathrm{Ca}$ dapat meningkatkan intensitas warna pada kain dengan pewarna kulit jengkol dibandingkan dengan pemakaian biomordan saja (K/S 3,70). Mordan kimia, yang dalam penelitian ini menggunakan ion $\mathrm{Ca}^{2+}$ ternyata memiliki afinitas yang lebih tinggi bila dibandingkan dengan mordan alam (tanin) sehingga dapat menjembatani ikatan antara pewarna dengan serat yang lebih kuat. Hal ini sejalan dengan penelitian yang menggunakan mordan logam dan biomordan dari daun Thuja occidentalis dan kulit buah delima (Ismal et al., 2014).

Nilai $a^{*} b^{*}$ pada kain yang diwarnai menunjukkan arah warna pada sistim koordinat warna kromatisasi. Koordinat $\mathrm{a}^{*}$ mewakili warna merah ketika positif dan hijau ketika negatif, dan koordinat $b^{*}$ mewakili warna kuning ketika positif dan biru ketika negatif (Islam et al., 2017).

Pada pewarnaan kain viskos dengan ekstrak kulit jengkol, terlihat bahwa perlakuan tanpa mordan dan gabungan biomordan gambir dengan mordan logam $\mathrm{Ca}$ memberikan arah warna yang lebih merah (a*) dibandingkan dengan pemakaian biomordan gambir (Tabel 1). Hal ini sesuai dengan hasil pewarnaan yang terlihat secara visual. Penggunaan biomordan gambir dapat merubah warna kain yang dicelup dengan ekstrak kulit jengkol yang semula berwarna merah agak keunguan menjadi merah kecoklatan. Hal ini disebabkan karena gambir juga merupakan komponen pembawa warna yang dapat memberikan warna merah kecoklatan pada kain (Failisnur et al., 2017).

Peningkatan konsentrasi biomordan dapat meningkatkan intensitas warna (K/S). Hasil ini sejalan dengan penelitian yang dilakukan terhadap pewarnaan wool dengan pewarna betanin menggunakan biomordan klorofil a (Guesmi et al., 2013). Penggabungan biomordan gambir dengan mordan $\mathrm{CaO}$ dapat lebih meningkatkan nilai intensitas warna (Tabel 1). Hal ini sesuai dengan penelitian penambahan mordan $\mathrm{Cu}$ pada biomordan biji Tamarin yang dapat meningkatkan nilai K/S pada pewarnaan kain katun, sutera dan wool (Prabhu and Teli, 2014). 
Tabel 1. Intensitas dan nilai beda warna serta hasil pewarnaan dari pewarnaan kain viskos

\begin{tabular}{|c|c|c|c|c|c|c|}
\hline \multicolumn{2}{|l|}{ Perlakuan } & $\mathrm{L}^{*}$ & $a^{*}$ & $b^{*}$ & $\mathrm{~K} / \mathrm{S}$ & Hasil Pewarnaan \\
\hline \multicolumn{2}{|l|}{ Tanpa Mordan } & 62,71 & 10,02 & 15,68 & 1,36 & \\
\hline \multirow{3}{*}{$\begin{array}{l}\text { Biomordan } \\
\text { gambir }\end{array}$} & $5 \%$ & 71,74 & 5,14 & 17,15 & 1,96 & \\
\hline & $10 \%$ & 70,98 & 5,19 & 18,22 & 2,28 & \\
\hline & $15 \%$ & 70,06 & 5,54 & 18,78 & 2,52 & \\
\hline \multicolumn{2}{|c|}{$\begin{array}{l}\text { Biomordan Gambir }+ \\
\text { mordan logam } \mathrm{Ca}^{+2}\end{array}$} & 62,16 & 12,64 & 25,28 & 3,70 & \\
\hline
\end{tabular}

\subsection{Ketahanan luntur warna}

Kain hasil pewarnaan diuji ketahanan luntur warnanya terhadap pencucian $40^{\circ} \mathrm{C}$ (perubahan dan penodaan warna) dan cahaya. Hasil uji dapat dilihat pada Tabel 2. Tabel 2 memperlihatkan bahwa penggunaan biomordan dapat meningkatkan nilai ketahanan luntur warna terhadap perubahan warna pada pencucian $40^{\circ} \mathrm{C}$ dari cukup (3) menjadi cukup sampai baik (3-4), penodaan warna terhadap kain lain pada pencucian $40^{\circ} \mathrm{C}$ dari baik (4) menjadi baik sampai sangat baik (4-5). Peningkatan nilai juga terjadi pada ketahanan luntur warna terhadap cahaya matahari dari cukup sampai baik (3-4) menjadi baik (4). Ketahanan luntur warna dari perlakuan dengan biomordan gambir dan penambahan mordan $\mathrm{CaO}$ tidak memberikan hasil yang berbeda.

Tabel 2. Hasil uji ketahanan luntur warna dari kain hasil pewarnaan

\begin{tabular}{lllll}
\hline \multirow{2}{*}{ Perlakuan } & \multicolumn{2}{l}{ Ketahanan Luntur Warna } \\
\cline { 3 - 4 } & \multicolumn{2}{l}{ Pencucian $40^{\circ} \mathrm{C}$} & \\
\cline { 3 - 4 } & & $\begin{array}{l}\text { Perubahan } \\
\text { Warna }\end{array}$ & $\begin{array}{l}\text { Penodaan } \\
\text { Warna }\end{array}$ & \\
\hline Tanpa Mordan & 3 & 4 & $3-4$ \\
\multirow{2}{*}{$\begin{array}{l}\text { Biomordan } \\
\text { gambir }\end{array}$} & $5 \%$ & 3 & $4-5$ & $3-4$ \\
\multicolumn{2}{l}{ Gambir $+\mathrm{CaOH}$} & $3-4$ & $4-5$ & 4 \\
\hline
\end{tabular}

Ketahanan luntur warna dari kain tanpa mordan terhadap pencucian $40^{\circ} \mathrm{C}$ dan cahaya pada umumnya lebih rendah dibandingkan dengan penggunaan biomordan (gambir) ataupun mordan kimia $(\mathrm{CaO})$. Hal ini disebabkan karena mordan (alam dan kimia) dapat menjembatani ikatan antara pewarna dan serat sehingga terbentuk kompleksitas yang dapat menahan zat warna terlepas dari serat pada saat pencucian ataupun pengaruh cahaya.

Ikatan antara zat warna dari kulit jengkol dengan serat kain viskos dapat terlepas pada saat proses pencucian. Tanin sebagai biomordan mengandung gugus hidroksil fenolik yang memungkinkan membentuk ikatan silang yang efektif antara serat dan pewarna (Prabhu and Teli, 2014). Biomordan gambir menyebabkan proses fiksasi pewarna yang lebih tinggi pada kain.

\section{Kesimpulan}

Penggunaan biomordan gambir pada pewarnaan kain viskos menggunakan pewarna kulit jengkol dapat meningkatkan nilai intensitas warna (K/S) dan ketahanan luntur warna dibandingkan dengan tanpa mordan. Peningkatan konsentrasi biomordan memberikan kenaikan pada intensitas warna, tetapi tidak terjadi peningkatan ketahanan luntur warna setelah penggunaan biomordan $10 \%$. Pemakaian biomordan gambir yang digabungkan dengan mordan kimia $\mathrm{CaO}$ dapat meningkatkan nilai intensitas warna, tetapi tidak terjadi peningkatan ketahanan luntur warna. Hasil analisa FTIR menunjukkan bahwa gugus fungsional berperan dalam penguatan serapan zat warna pada kain viskos, terutama gugus fungsi hidroksil dan karboksil.

\section{Ucapan terima kasih}

Terima kasih kami sampaikan kepada Balai Riset dan Standardisasi Industri Padang yang telah membantu pendanaan sehingga penelitian dapat berjalan dengan baik dan lancar. Terima kasih juga disampaikan kepada Marlusi, Sulastri, dan Prasemiati Ningsih yang telah membantu kelancaran penelitian ini.

\section{Daftar pustaka}

Failisnur, F., Sofyan, S., Hermianti, W., 2017. Pemanfaatan limbah cair pengempaan gambir untuk pewarnaan kain batik. J. Litbang Ind. 7, 19. https://doi.org/10.24960/jli.v7i1.2695.19-28

Failisnur, F., Sofyan, S., Kasim, A., Angraini, T., 2018. Study of cotton fabric dyeing process with some mordant methods by using gambier (Uncaria gambir Roxb) extract. Int. J. Adv. Sci. Eng. Inf. Technol. 8, 1098-1104. https://doi.org/10.18517/ijaseit.8.4.4861 
Failisnur, Sofyan, 2014. Sifat tahan luntur dan intensitas warna kain sutera dengan pewarna alam gambir (Uncaria gambir Roxb) pada kondisi pencelupan dan jenis fiksator yang berbeda. J. Litbang Ind. 4, 1-8. https://doi.org/ 10.24960/jli.v4i1.634.1-8

Ghaheh, F.S., Mortazavi, S.M., Alihosseini, F., Fassihi, A., Shams Nateri, A., Abedi, D., 2014. Assessment of antibacterial activity of wool fabrics dyed with natural dyes. J. Clean. Prod. 72, 139-145. https://doi.org/ 10.1016/j.jclepro.2014.02.050

Guesmi, A., Ladhari, N., Hamadi, N. Ben, Msaddek, M., Sakli, F., 2013. First application of chlorophyll-a as biomordant: Sonicator dyeing of wool with betanin dye. J. Clean. Prod. 39, 97-104. https://doi.org/ 10.1016/j.jclepro.2012.08.029

Islam, S., Rather, L.J., Shabbir, M., Bukhari, M.N., Shahid, M., Ali Khan, M., Mohammad, F., 2017. Bi and tri metal salt combinations plus colorants extracted from timber industry waste as effective dyeing materials to produce novel shades on wool. J. Nat. Fibers 14, 586-596. https://doi.org/10.1080/ 15440478.2016.1240638

Ismal, Ö.E., Yildirim, L., Özdodagan, E., 2014. Use of almond shell extracts plus biomordants as effective textile dye. J. Clean. Prod. 70, 61-67. https://doi.org/10.1016/j.jclepro.2014.01.055

Khan, M.A., Islam, S.-U., Mohammad, F., 2016. Extraction of natural dye from walnut bark and its dyeing properties on wool yarn. J. Nat. Fibers 13, 458-469. https://doi.org/10.1080/15440478.2015. 1055033

Liang, S., Guo, X., Feng, N., Tian, Q., 2010. Isotherms, kinetics and thermodynamic studies of adsorption of $\mathrm{Cu} 2+$ from aqueous solutions by $\mathrm{Mg} 2+/ \mathrm{K}+$ type orange peel adsorbents. J. Hazard. Mater. 174, 756762. https://doi.org/10.1016/j.jhazmat.2009.09.116

Masae, M., Sikong, L., Choopool, P., Pitsuwan, P., Sriwittayakul, W., Bonbang, A., Kimthong, N., 2017. Dyeing silk fabrics with stink bean pod (Parkia speciosa Hassk.) natural dye in the color fastness and UV protection. J. Eng. Sci. Technol. 12, 1792-1803.

Prabhu, K.H., Teli, M.D., 2014. Eco-dyeing using Tamarindus indica L. seed coat tannin as a natural mordant for textiles with antibacterial activity. J. Saudi Chem. Soc. 18, 864-872. https://doi.org/ 10.1016/j.jscs.2011.10.014

Punrattanasin, N., Nakpathom, M., Somboon, B., Narumol, N., Rungruangkitkrai, N., Mongkholrattanasit, R., 2013. Silk fabric dyeing with natural dye from mangrove bark (Rhizophora apiculata Blume) extract. Ind. Crops Prod. 49, 122 129. https://doi.org/10.1016/j.indcrop.2013.04.041

Saxena, S., Raja, A.S.M., 2014. Natural dyes: Sources, chemistry, application and sustainability issues. Springer Science+Business Media Singapore 2014, pp. 41-62. https://doi.org/10.1007/978-981-287-065-0

Sofyan, S., Failisnur, F., 2017. Reuse of liquid waste from textile dyeing with natural dyes gambier (Uncaria gambir Roxb.) for cotton yarn dyeing. ARPN J. Eng. Appl. Sci. 12, 5313-5318.

Sofyan, S., Failisnur, F., Silfia, S., 2018. The effect of type and method of mordant towards cotton fabric dyeing quality using jengkol (Archidendron jiringa) pod waste. J. Litbang Ind. 8, 1-9. https://doi.org/ 10.24960/jli.v8i1.3830.1-9

Sulistyani, M., Huda, N., 2017. Optimasi pengukuran spektrum vibrasi sampel protein menggunakan spektrofotometer fourier transform infrared ( FT-IR ). Indones. J. Chem. Sci. 6, 173-180.

Wangatia, L.M., Tadesse, K., Moyo, S., Wangatia, L.M., Tadesse, K., Moyo, S., 2015. Mango bark mordant for dyeing cotton with natural dye: Fully eco-friendly natural dyeing. Int. J. Text. Sci. 4, 36-41. https://doi.org/10.5923/j.textile.20150402.02

Yang, T.T., Guan, J.P., Chen, G., Tang, R.C., 2018. Instrumental characterization and functional assessment of the two-color silk fabric coated by the extract from Dioscorea cirrhosa tuber and mordanted by iron salt-containing mud. Ind. Crops Prod. 111, 117-125. https://doi.org/10.1016/ j.indcrop.2017.10. 016

Zarkogianni, M., Mikropoulou, E., Varella, E., Tsatsaroni, E., 2011. Colour and fastness of natural dyes: Revival of traditional dyeing techniques. Color. Technol. 127, 18-27. https://doi.org/10.1111/ j.14784408.2010.00273.x 